\title{
LOSS OF THE ZONA PELLUCIDA IN MICE, AND THE EFFECT OF TUBAL LIGATION AND OVARIECTOMY
}

\author{
MARGARET WARD ORSINI AND ANNE MGLAREN
}

\author{
Department of Anatomy, University of Wisconsin, and \\ A.R.C. Unit of Animal Genetics, Institute of Animal Genetics, Edinburgh
}

(Received 12th September 1966)

\begin{abstract}
Summary. Loss of the zona pellucida begins late on the 4th day of gestation in the mouse. By 23.00 hours, about half the blastocysts are zona-free. Pontamine Blue sensitivity, indicating the first stage of attachment, begins at about the same time, or a little later.

Once the zona is lost, recovery of blastocysts becomes increasingly difficult. However, because attachment in the early stages is very superficial, some zona-free blastocysts can be flushed out of the uterus up to the evening of the 5th day of gestation. The decidual reaction develops during the middle of the 5th day.

Loss of the zona pellucida is delayed by about $12 \mathrm{hr}$ when the ova are retained in the oviducts by ligation, and for a longer period when ovariectomy is performed early in pregnancy. In such females, no Pontamine Blue reaction is observed in the uterus. Under these experimental conditions, fracture of the zona eventually occurs, probably owing to active pulsating movements on the part of the blastocyst; the blastocyst may remain for a time within the ruptured zona, or may emerge. In a normal, oestrogen-stimulated uterus, loss of the zona also seems to be by hatching, but in addition some hormonally-determined uterine factor is probably acting on the zona to weaken it, and thus accelerate the process of emergence of the blastocyst.
\end{abstract}

\section{INTRODUCTION}

Blastocysts free of the zona pellucida are present in the uteri of mice on the 5 th day of pregnancy; the zona is therefore presumably lost during the course of that day or the preceding night. The aim of the present investigation was to determine more precisely the time of loss of the zona in a particular strain of mice, both chronologically and in relation to the time of appearance of the Pontamine Blue reaction. This reaction is an index of increased uterine capillary permeability: after intravenous injection of the dye, discrete blue areas mark the location of blastocysts within the uterus, at a stage before the decidual reaction has developed. Geigy Blue was used for a similar purpose by Psychoyos $(1960,1961)$ in the rat, and Pontamine Blue has been used extensively by Orsini $(1963,1964,1965$ a) in pregnant and pseudo-pregnant hamsters. 
We were also concerned to see whether the loss of the zona pellucida in mice was delayed by: (a) retention of the embryos in the oviduct by ligation, and (b) removal of the ovaries early in pregnancy. In hamsters, the first treatment delays the loss of the zona, and the second prevents it completely (Orsini, 1965b).

\section{MATERIALS AND METHODS}

Nulliparous females of the randomly bred $Q$ strain were caged with $Q$-strain males of proved fertility, and inspected for copulation plugs each morning. The day on which the copulation plug was found was considered the first day of pregnancy; 01.00 hours on that day was reckoned as the hour of ovulation, and all autopsies and procedures were timed from that point. All animals were reared and maintained in the Institute of Animal Genetics, Edinburgh, under normal lighting conditions.

The females were killed at known post-ovulation stages, 15 min after the intravenous injection of $0.25 \mathrm{ml}$ of a $0.5 \%$ or $1 \%$ solution in normal saline of Pontamine Sky Blue 5BX (more recent tests have shown that $0.15 \mathrm{ml}$ of a $0.5 \%$ solution is equally effective). The numbers and gross appearance of discrete blue sites in the uterus were recorded, then one oviduct and/or uterine horn was flushed into a watch glass with phosphate-buffered saline and the number, condition and stage of development of the ova recorded. The ova were usually photographed, using a Micro-Ibsco on a Zeiss microscope. The number of corpora lutea on the ovaries was also usually recorded. The corpora lutea were not always easy to count at this early stage of gestation, especially when their numbers were large: the figures given should therefore be regarded as approximations.

Uterine horns were flushed into a watchglass under a dissecting microscope, either by a hypodermic needle inserted and clamped into the upper uterus, or by a fine pipette. Since the portion of uterus used for insertion is not itself adequately flushed, a small proportion even of unattached ova must have been missed. More delicate procedures, such as flushing from the oviduct, or 'ballooning' the uterus so as to detach ova which had begun to attach, were tried but proved too time-consuming and capricious to adopt as routine procedures. Flushed and unflushed uteri were fixed in AFA $(30 \mathrm{ml} \mathrm{95 \%}$ alcohol, $10 \mathrm{ml}$ commercial formalin, $10 \mathrm{ml}$ glacial acetic acid, $50 \mathrm{ml}$ water), dehydrated and cleared by the benzyl-benzoate technique (Orsini, 1962), and re-examined, before histological section. Gross photography of the cleared material was done with the same camera on a Bausch \& Lomb wide-field dissecting microscope.

To investigate the effect of unilateral tubal ligation, a fine ligature was tied around the uterine end of the straight segment of the oviduct, during the afternoon of the 2nd day of gestation (about 1 day $16 \mathrm{hr}$ after ovulation). Pontamine Blue was injected and the animals killed during the 4th to 7 th days of gestation. The number of implantation sites on the control, unligated side was noted; the ligature was then removed on the ligated side, and the oviduct flushed.

To determine the effect of ovariectomy, the ovaries were removed, using 
ether anaesthesia, during the later part of the 2nd or 3rd day of gestation. A $5 \mathrm{X}$ head loop magnifier was worn while operating. The ovariectomized mice were autopsied after Pontamine Blue injection on the 5th day.

\section{RESULTS}

Normal development

Data on twenty-five females killed between 22.00 hours on the 4th day of pregnancy (3 days $21 \mathrm{hr}$ after ovulation) and 02.45 hours on the 5 th day

TABLE 1

OBSERVATIONS ON TWENTY-FIVE Q-STRAIN FEMALES, KILLED BETWEEN 22.00 HOURS ON THE 4TH DAY OF GESTATION AND 02.45 HOURS ON THE 5TH DAY

\begin{tabular}{|c|c|c|c|c|c|c|c|c|}
\hline \multirow{3}{*}{$\begin{array}{c}\text { Time } \\
\text { killed } \\
(G . M . T .)\end{array}$} & \multicolumn{6}{|c|}{ Uterine horn flushed } & \multicolumn{2}{|c|}{ Uterine horn fixed } \\
\hline & \multirow{2}{*}{$\begin{array}{l}\text { Corpora } \\
\text { lutea }\end{array}$} & \multirow{2}{*}{$\begin{array}{c}\text { Pontamine } \\
\text { Blue }\end{array}$} & \multicolumn{2}{|c|}{ Fertilized ova } & \multirow{2}{*}{$\begin{array}{l}\text { Unfert- } \\
\text { ilized or } \\
\text { abnormal }\end{array}$} & \multirow{2}{*}{ Zonae } & \multirow{2}{*}{$\begin{array}{c}\text { Corpora } \\
\text { lutea }\end{array}$} & \multirow{2}{*}{$\begin{array}{c}\text { Pontamine } \\
\text { Blue }\end{array}$} \\
\hline & & & In zona & Free & & & & \\
\hline 22.00 & - & 0 & 3 & 0 & 0 & 0 & - & 0 \\
\hline 22.00 & 3 & 0 & 1 & 0 & 2 & 0 & 9 & 0 \\
\hline 22.05 & 8 & 0 & 4 & 1 & 0 & 0 & - & 0 \\
\hline 22.20 & 7 & 3 & \multicolumn{3}{|c|}{ (Flushing unsuccessful) } & & - & \\
\hline 22.30 & $3-4$ & 0 & 3 & 0 & 0 & 0 & 10 & 0 \\
\hline 22.30 & 4 & 0 & 4 & 0 & 0 & 0 & - & 0 \\
\hline 22.35 & 7 & 0 & 5 & 0 & 1 & 0 & - & 0 \\
\hline 22.50 & 8 & 0 & 7 & 0 & 0 & 0 & - & 0 \\
\hline 23.00 & 9 & $4-5$ & 0 & 7 & 0 & 0 & 6 & $5-6$ \\
\hline 23.05 & $7-8$ & 3 & 0 & 8 & 0 & 7 & 5 & 4 \\
\hline 23.10 & 9 & 7 & 0 & 0 & 0 & 0 & - & 8 \\
\hline 23.10 & - & 3 & 0 & I & 0 & 0 & - & 8 \\
\hline 23.25 & 9 & $3-4$ & 2 & 2 & 0 & 0 & - & 2 \\
\hline 23.30 & 6 & 4 & 1 & 2 & 2 & 0 & 9 & $5-6$ \\
\hline 23.40 & 6 & 4 & 1 & 2 & 0 & 0 & - & 6 \\
\hline 23.50 & - & 3 & 2 & 1 & 0 & 0 & - & 7 \\
\hline 24.00 & 6 & 2 & 2 & 1 & 0 & 0 & - & 5 \\
\hline 24.05 & 9 & $5-6$ & 0 & 0 & 0 & $6-7$ & 9 & 5 \\
\hline 24.25 & 9 & 6 & 0 & 2 & 0 & 0 & - & 1 \\
\hline 24.45 & - & $5^{*}$ & 0 & 2 & 0 & 0 & - & 5 \\
\hline 24.45 & 9 & & 3 & 0 & 0 & 4 & 8 & \\
\hline 24.45 & 5 & $4-5$ & 0 & 4 & 0 & 0 & - & $4-5$ \\
\hline 01.15 & $5-6$ & $4-5 *$ & 0 & 1 & 0 & 0 & - & $5-6$ \\
\hline 01.55 & 5 & 2 & 1 & 1 & 1 & 0 & - & 5 \\
\hline 02.45 & - & 1 & it & 0 & 0 & 0 & - & $2+?$ \\
\hline
\end{tabular}

Here and in later tables, the numbers of unfertilized eggs do not include 'ghosts', which almost certainly derive from an earlier ovulation.

* Only part of the uterine horn was flushed.

$\dagger$ Zona irregular, moulded to contour of blastocyst.

(4 days $1 \frac{3}{4} \mathrm{hr}$ after ovulation) were collected on three occasions, in May, June and July respectively. Pontamine Blue reactions were recorded, one uterine horn was flushed, the other was fixed for clearing and histological examination. In twenty of the females, corpora lutea were counted. The three occasions gave consistent results and have therefore been combined. Macroscopic observations are listed in Table 1.

The total number of ova recovered by flushing decreased with time, as the 
blastocysts became more firmly attached to the uterus. Of the twenty-two females in which one whole uterine horn was successfully flushed, the first eleven gave a mean of 4.3 ova recovered, the second eleven a mean of 2.5 ova recovered. The negative regression of number of ova on time was significant $(P<0 \cdot 01)$.

The earliest female from which a zona-free blastocyst was recovered was killed at 22.05 hours, while from 23.00 hours onwards, zona-free blastocysts were common. The calculation of a ' $50 \%$-loss point' is complicated by the greater difficulty of recovering blastocysts once the zona is lost. In Text-fig. 1, the number of blastocysts recovered in the zona is expressed for each uterine horn as a percentage of the total number of blastocysts, estimated from the number of corpora lutea on the corresponding ovary minus the number of

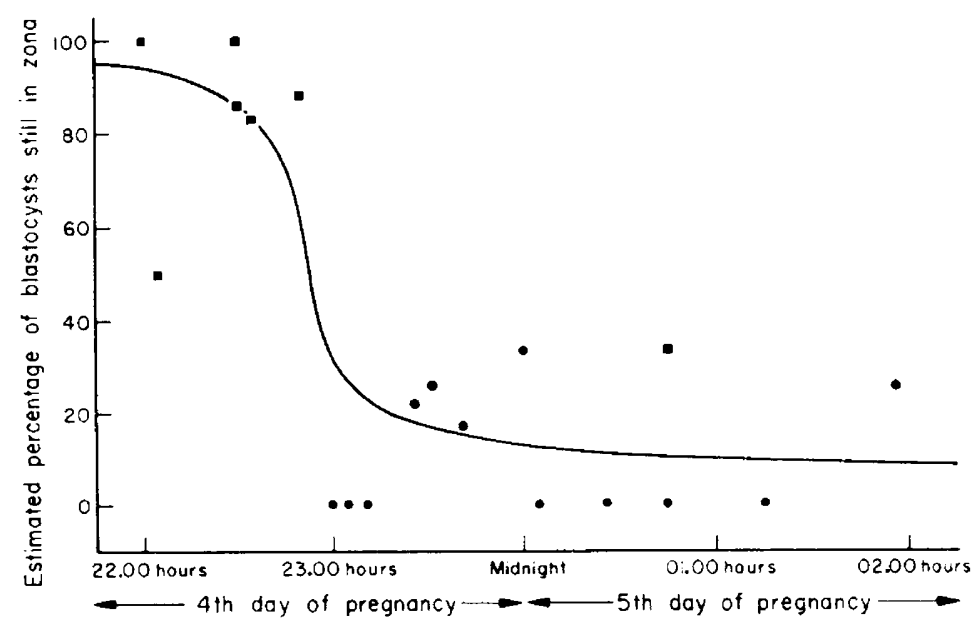

Texr-FIG. 1. The time of loss of the zona pellucida. Only those females in which corpora lutea were counted are represented. The total number of blastocysts in the flushed horn is estimated as the number of corpora lutea on the ovary minus the number of unfertilized ova recovered. The estimated percentage of blastocysts still in the zona is calculated from the number of blastocysts recovered with the zona intact, expressed as a percentage of the estimated total number of blastocysts. The curve was drawn by eye. $\mathbf{\square}$, Female negative for Pontamine Blue reaction; $\boldsymbol{\theta}$, female positive for Pontamine Blue reaction.

unfertilized eggs recovered. From these data, it would appear that half the blastocysts on average had become zona-free shortly before 23.00 hours. As pointed out earlier, neither corpora lutea counts nor recovery techniques were $100 \%$ efficient; however, it seems unlikely that errors from this source would affect the estimate of time of loss of the zona by more than half an hour.

Plate 1, Figs. 1 to 5 show some of the ova recovered. Note the general rounded shape of the blastocysts while in the zona (Pl. 1, Figs. 1 and 4), with only a slight indication of a longer axis (P1. 1, Figs. 3 and 4), and the enlargement and elongation of the blastocysts after loss of the zona (Pl. 1, Figs. 4 and $5)$. Some variation in stage of development within the same uterine horn was observed (Pl. 1, Figs. 1 and 4).

The earliest female to show Pontamine Blue areas was killed at 22.20 hours; all but one of the seventeen flushed between 23.00 hours and 02.45 hours were 
positive for Pontamine Blue. The number of Pontamine Blue areas in the positive uteri did not increase with time, which suggests that throughout any given uterine horn, Pontamine Blue reactivity develops over a relatively short period. Text-fig. 1 shows that a good correlation existed between loss of the zona pellucida and appearance of Pontamine Blue areas.

In three instances, crumpled zonae were flushed from the uterus. These were fractured and usually semi-opaque, and readily distinguishable from the empty intact zonae, or 'ghosts', which represent a late stage of degeneration of unfertilized ova. In one female the zonae were almost equal in number to the zona-free blastocysts recovered, and had presumably been recently shed; in the other two females, the number of corpora lutea was consistent with the view that the zonae came from blastocysts already beginning to attach.

Eighteen of the twenty-five animals killed during the night were re-examined after clearing. The blue sites varied from pale, poorly outlined areas to distinct blue regions. When viewed from the anti-mesometrial surface, the lumen lay more centrally in the conceptual than in the interconceptual areas, but none of the areas showed the clear luminal changes which are associated with the earliest appearance of Pontamine Blue sensitivity in the hamster.

The cleared, unflushed horns of three females showing no Pontamine Blue areas (killed at $22.00,22.30$ and 24.45 hours) were sectioned serially to check that they contained fertilized ova. The three horns contained six, seven and five ova respectively.

Individual Pontamine Blue areas were cut out from the cleared unflushed horns of six females killed at 23.10, 23.40, 23.50, 24.45, 01.15 and 01.55 hours respectively, and sectioned serially. In each area a zona-free blastocyst was found lying in a cavation at the anti-mesometrial end of the uterine lumen. In some of the sections, the blastocyst was in contact with the epithelial cells by processes from the trophoblast (Pl. 1, Fig. 6). Although each blastocyst showed this contact, it was not visible in every section and so must represent only the initial process of nidation. The dark body entering the uterine epithelium in Pl. 1, Fig. 6, is one of the W-bodies (Finn \& McLaren, 1967) associated with the primary invasive cells described by Wilson (1963). The epithelium of the cavation was slightly flattened, about half the height of the mesometrial epithelium, and some of its nuclei were compressed or showed early evidence of necrosis.

No true decidua was present in any of these sites, although the stromal cells were beginning to round up, and mitotic figures, rare in the female killed at 23.10 hours, became increasingly evident in the later sites. Oedema was more marked in the sections near the implanting blastocyst than in those further away.

Thus the night series indicates that the first Pontamine Blue reactivity appears in the very last hours of the 4th day, closely associated with the time of loss of the zona pellucida, and in the early hours of the 5th day. At this time no distinct luminal changes are yet present. Attachment begins almost simultaneously, and is thus predecidual.

Subsequent gross morphological changes and their histological concomitants were observed by combining observations on the control normal side in the 
tubal-ligation series with those on normal animals killed at intervals throughout the subsequent days. By the morning of the 5 th day ( 4 days $7 \mathrm{hr}$ after ovulation onwards), all pregnant females were positive for the Pontamine Blue reaction. By flushing the uteri with extreme care, a few zona-free blastocysts could still be recovered. By 4 days and $8 \mathrm{hr}$ after ovulation ( 08.55 hours on the 5 th day) there were definite indications of luminal changes in the uterus where the blue was present. By 4 days and $9 \frac{1}{2} \mathrm{hr}$, there were distinct luminal changes, and in some few instances there was slight cloudiness within conceptual areas along a single uterus.

The next development after the luminal changes and cloudiness at the centre of the conceptual regions, was a slight localized opacity at the very centre of each conceptual area bordering on the lumen. This opacity did not appear simultaneously at all sites within a uterus. By 4 days and $11 \mathrm{hr}$ the luminal changes were obvious, there was cloudiness near the lumen, and immediately bordering the lumen there was a definite white rim which was the first indication of the opacity. By 4 days and $16 \mathrm{hr}$, approximately half the sites showed development of the opacity.

Histological sections were made of a site removed from the control horn of the female from the tubal ligation series, autopsied at 4 days and $11 \mathrm{hr}$ after ovulation. Luminal changes were evident, there was a diffuse cloudiness near the lumen, and, when viewed from the anti-mesometrial surface, a fine white rim near the lumen. The sections show a definite thick zone of enlarging cells (early decidua) immediately beneath the uterine epithelium at the implantation site and extending laterally for some distance. The large distended blastocyst, attached at several points to epithelial cells, tends to collapse away from the epithelium which itself is easily detached from the stroma. The attachment is still limited in comparison with the entire circumference of the blastocyst, and appears as points penetrating between the epithelial cells.

On the 6th day (5 days, $10 \mathrm{hr}$ after ovulation), pronounced endometrial swelling was obvious in the cleared specimens. In the mesometrial view a distinct white opaque circle was seen, made up of two hemicircles, one on either side of the uterine lumen. In lateral view this appeared as an opacity lying in the mesometrial centre of the enlarged conceptual area, from which opaque strands extend down towards the anti-mesometrial side. By now the elongating egg cylinder has displaced the epithelium in the implantation area, and in the more anti-mesometrial portion of the lumen the epithelium is also rounding up before degeneration. Well developed trophoblastic giant cells line the implantation cavity. Decidua is prominent at both lateral and antimesometrial sides of the implanted cylinder and extends mesometrially as well.

On the 7th day, 6 days and $10 \mathrm{hr}$ after ovulation, a white opaque dot has appeared approximately at the centre in the lateral view, and a cloudiness extends throughout the entire mesometrial portion, corresponding to the developing decidua. A V-shaped area of dense opacity lies within the cloudy zone, with the apex pointed toward the mesometrial side, beneath which lies the dot, at approximately the centre of the conceptual area (Pl. 1, Fig. 7). Sections show a well developed ectoplacental cone and Träger, with thick decidua (Pl. 1, Fig. 8). 


\section{Effect of unilateral tubal ligation}

In seventeen pregnant females, the ova on one side were retained in the oviduct by means of a ligature. The females were killed at intervals from the 4 th to the 7th day of gestation, and the ova examined (Table 2). On the control side, the time of loss of the zona, and time of appearance of Pontamine Blue reactivity, were consistent with that described in the last section. Of the nine females autopsied during the 5th day of gestation, the eight given Pontamine Blue showed distinct blue areas in the control horn, while the one animal not given blue showed four areas of luminal changes in the control, unflushed horn after clearing. Zona-free blastocysts (Pl. 2, Fig. 2) and broken zonae

TABLE 2

THE EFFEGT OF UNILATERAL TUbal Ligation (AT 1 DAY, 16-17 HR AFTER OVULATION) ON THE LOSS OF THE ZONA PELLUGIDA

\begin{tabular}{|c|c|c|c|c|c|c|c|c|c|c|}
\hline \multirow{3}{*}{$\begin{array}{l}\text { Day of } \\
\text { pregnancy }\end{array}$} & \multirow{3}{*}{$\begin{array}{c}\text { Time } \\
\text { killed } \\
(G . M . T .)\end{array}$} & \multicolumn{4}{|c|}{ Contral side } & \multicolumn{5}{|c|}{ Ligated side } \\
\hline & & \multirow{2}{*}{$\begin{array}{l}\text { Ponta- } \\
\text { mine } \\
\text { Blue }\end{array}$} & \multicolumn{2}{|c|}{ Embryos } & \multirow{2}{*}{ Zonae } & \multirow{2}{*}{$\begin{array}{c}\text { Corpora } \\
\text { lutea }\end{array}$} & \multicolumn{2}{|c|}{ Embryos } & \multirow{2}{*}{$\begin{array}{l}\text { Unfert- } \\
\text { ilized }\end{array}$} & \multirow{2}{*}{ Zonas } \\
\hline & & & In zona & Free & & & In zona & Free & & \\
\hline 4th & $\begin{array}{l}15.45 \\
19.50 \\
20.30 \\
20.45\end{array}$ & $\begin{array}{l}0 \\
- \\
\overline{0}\end{array}$ & $\begin{array}{l}5 \\
0^{*} \\
1^{*} \\
3^{*}\end{array}$ & $\begin{array}{l}0 \\
4 \\
0 \\
0\end{array}$ & $\begin{array}{l}0 \\
0 \\
0 \\
0\end{array}$ & $\begin{array}{l}- \\
\overline{6} \\
0\end{array}$ & $\begin{array}{l}6 \\
4 \\
4+1 \\
6\end{array}$ & $\begin{array}{l}0 \\
0 \\
0 \\
0\end{array}$ & $\begin{array}{l}0 \\
0 \\
0 \\
0\end{array}$ & $\begin{array}{l}0 \\
0 \\
0 \\
0\end{array}$ \\
\hline 5 th & $\begin{array}{l}08.55 \\
10.30 \\
10.50 \\
11.30 \\
12.00 \\
13.45 \\
16.05 \\
17.10 \\
17.45\end{array}$ & $\begin{array}{r}6 \\
8 \\
- \\
7 \\
7 \\
2 \\
5 \\
6 \\
11\end{array}$ & 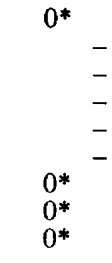 & $\begin{array}{l}1 \\
1 \\
2\end{array}$ & $\begin{array}{l}0 \\
1 \\
0\end{array}$ & $\begin{array}{c}6-7 \\
- \\
8 \\
3 \\
6 \\
- \\
7 \\
5 \\
8\end{array}$ & $\begin{array}{l}6 \\
3 \\
0 \\
3 \\
1 \\
1 \dagger \\
5+1 \ddagger \\
1 \dagger \\
2\end{array}$ & $\begin{array}{l}0 \\
0 \\
4 \\
1 \\
4 \\
0 \\
1 \\
1 \\
5\end{array}$ & $\begin{array}{l}0 \\
0 \\
0 \\
0 \\
0 \\
0 \\
1 \\
0 \\
0\end{array}$ & $\begin{array}{l}0 \\
0 \\
8 \\
1 \\
4 \\
0 \\
1 \\
0 \\
0\end{array}$ \\
\hline 6 th & $\begin{array}{l}08.45 \\
10.45 \\
10.45\end{array}$ & $\begin{array}{l}5 \\
5 \\
9\end{array}$ & $0^{*}$ & 0 & 0 & $\begin{array}{l}9 \\
7 \\
6\end{array}$ & $\begin{array}{l}0 \\
0 \\
0\end{array}$ & $\begin{array}{l}2 \\
2 \\
3+2+\end{array}$ & $\begin{array}{l}1 \\
0 \\
1\end{array}$ & $\begin{array}{l}1 \\
5 \\
2\end{array}$ \\
\hline 7 th & 11.30 & 4 & - & & & 7 & 0 & $0+5 \ddagger$ & 0 & 5 \\
\hline
\end{tabular}

were recovered from these control horns Although implantation had been initiated in the control horns, as indicated by the blue areas and luminal changes, no localized blue was ever present in the uterus on the ligated side, and loss of the zona was delayed by more than $12 \mathrm{hr}$. At 4 days $8 \mathrm{hr}$ and 4 days $9 \frac{1}{2} \mathrm{hr}$ after ovulation, all ova retained in the oviduct were still within the zonae, and mixed clutches, some blastocysts in zonae and some free, were recovered as late as 4 days, $17 \mathrm{hr}$ after ovulation (Pl. 2, Fig 4). Hatching from the zona was observed in two females (Pl. 2, Figs. 3 and 5), but at an obviously delayed period.

By the 6th and 7th days, all the fertilized ova had hatched, and cracked 
zonae were recovered from the oviduct. Some of the tube-locked ova had already begun to degenerate.

Two of the four portions of control tracts flushed resulted in recovery of zonae, including one obviously broken but rounded, two with a crack like a fine hair, and one crumpled. In form, these zonae closely resembled those recovered from oviducts, suggesting that they were from the latest ovulation and not remnants of older unfertilized ova.

Study of the tube-locked blastocysts revealed marked disparity in size (Pl. 2, Fig. 1). Some blastocysts were expanded, distending the zona to a fine thin rim, others had a space between the blastocyst and the zona. The zona acts as a restraining mechanism, resulting in a rounded shape; as soon as they are free the blastocysts assume a slightly elongate shape, with the inner cell mass end often pointed. In several instances the expanded blastocysts were observed to contract within the zona very suddenly while under observation; in the contracted state they were difficult to distinguish from morulae. In no instance was any sudden distension noted.

TABLE 3

THE CONDITION OF BLASTOCYSTS IN SEVEN FEMALES OVARIEGTOMIZED ON THE 2ND OR 3RD DAY OF GESTATION, AND KILLED ON THE 5TH DAY (4 DAYS 8 HR TO 4 DAYS 16 HR AFTER OVULATION)

\begin{tabular}{c|c|c|c|c|c|c}
\hline $\begin{array}{c}\text { Time } \\
\text { killed } \\
(\text { G.M.T. }\end{array}$ & \multicolumn{3}{|c|}{ Normal ova } & Abnormal, & Unfertilized & $\begin{array}{c}\text { Broken } \\
\text { zonae }\end{array}$ \\
\cline { 2 - 5 } in zona & In zona & Zona cracked & Free & & 0 \\
\hline 08.45 & $10^{*}$ & 0 & 2 & 0 & 0 & 0 \\
11.00 & 8 & 0 & 0 & 1 & 0 & 0 \\
11.05 & 1 & 0 & 0 & 6 & 0 & 0 \\
12.25 & 2 & 3 & 0 & 0 & 3 & 0 \\
13.00 & 6 & 2 & 0 & 2 & 0 & 2 \\
14.30 & 4 & 0 & 0 & 0 & 2 & 0 \\
17.00 & 1 & 0 & 0 & 2 & 2 & \\
\hline
\end{tabular}

Some of those classified as unfertilized may have been very degenerate fertilized ova.

* Three of these blastocysts were recovered from the oviduct.

\section{Effect of ovariectomy}

Ovariectomy on the 2nd or 3rd day of pregnancy produced an even more striking effect on the loss of the zona than did tubal ligation. Of fifty fertilized ova recovered from seven ovariectomized females on the 5th day of pregnancy, only two were free of the zona (Table 3 ). A further five were lying within zonae which showed cracks or large splits (Pl. 3, Figs. 1, 6 and 7), and two broken empty zonae were recovered (Pl. 3, Fig. 2). Three of the females (including the one with two free blastocysts) were tested for Pontamine Blue reactivity, but in no instance were blue areas found. Five females ovariectomized on the 2nd day and one on the 3rd day of pregnancy yielded no eggs or zonae, and have not been included in the Table.

As may be seen from Pl. 3, Fig. 3, ovariectomy resulted in marked degeneration among the ova recovered, but at least one apparently normal blastocyst was recovered from each animal, and in many instances more (Pl. 3, Fig. 4). 


\section{DISCUSSION}

In rats, Dickmann \& Noyes (1961) showed that the zona pellucida is shed during the afternoon of the 5th day of gestation. No comparable data have, until recently, been available for mice: indeed, Snell (1956) wrote of the loss of the zona pellucida of the mouse, 'neither the exact time nor mechanism is thoroughly known'.

Enzmann, Saphir \& Pincus (1932) mentioned that the mouse zona persists till the end of the 5th day, but gave no indication of how extensive their observations on this point were. We find that, in our animals under our conditions of management, loss of the zona takes place considerably earlier: apart from one animal from the tube-locked series with zona-free blastocysts within the uterus during the afternoon of the 4th day, our evidence supports the normal time for loss of the zona pellucida as beginning in the evening of the 4th day. Fifty per cent of blastocysts are already zona-free by 23.00 hours on the 4 th day (i.e. 3 days $22 \mathrm{hr}$ after ovulation). Our findings are in good agreement with those of Dickson (1966).

The advent of Pontamine Blue reactivity in the uterus coincides in time very closely with the loss of the zona. If anything, loss of the zona slightly precedes the appearance of Pontamine Blue sensitivity, which itself is associated with the first delicate attachment of the implanting ova into a pre-decidual uterus. All three phenomena, loss of zona, appearance of blue and attachment, appear to be closely associated within a 'clutch', though not simultaneous for all ova. They also appear to be closely similar in time for all females of a particular strain.

Dickmann \& Noyes (1961) and Dickson (1966) found that once the zona had been lost, fewer blastocysts could be recovered by flushing the uterus, presumably because attachment had already begun. Our finding of a decline with time in the number of blastocysts recovered supports this point. However, the first attachment is extremely superficial and easily broken, since some ova which have attached can still be recovered by flushing. It is not until after advanced attachment and development of decidua late on the 5th day that recovery becomes impossible. This partly explains the variation in dating of implantation as reported by various investigators; the process of implantation is actually initiated in the very last hours of the 4th day and the degree and extent of intimacy increases during the 5 th day.

In many species, the time at which the zona is lost appears to depend more upon the uterine environment than upon the developmental stage of the blastocyst. In the hamster, Orsini $(1963,1964,1965 \mathrm{a}, \mathrm{b})$ has found that loss of the zona is strongly progesterone-dependent: the zona is lost from ova in the uteri of pregnant or pseudopregnant females, but retained in ova of unmated hamsters unless these are given exogenous progesterone. No loss of the zona occurs from ova of either pregnant or pseudopregnant hamsters ovariectomized during the second day of gestation. When ova were retained within the oviduct unilaterally by a ligature at the utero-tubal junction, implantation proceeded normally in the control horn, but loss of the zona from the blastocysts in the oviduct was delayed (Orsini, 1965a, b). 
In mice and rats, loss of the zona has been thought to be largely independent of the uterine environment. However, our observation that loss of the mouse zona is postponed by about $12 \mathrm{hr}$ if the blastocysts are retained in the oviduct by ligation, and by a rather longer period if both ovaries have been removed early in pregnancy, is not in serious conflict with earlier studies. These have sought primarily to show that the zona can still be lost even if the blastocyst is not in a progestational uterus, rather than to establish the exact time of loss relative to the control situation. Burdick, Whitney \& Pincus (1937) stated that mouse ova tube-locked by oestrogen treatment 'lose the zona pellucida at about the normal time', but their published data do not exclude a delay of several hours on the part of the tube-locked blastocysts. Tarkowski (1962) mentioned that loss of the zona is delayed if rat blastocysts are transferred to mouse oviducts. Loss of the zona pellucida has been shown to occur during delay in implantation of blastocysts, both in hypophysectomized rats (Cochrane, Prasad \& Meyer, 1962), and in genetically sterile or sexually immature mice, whether intact or hypophysectomized (Smithberg \& Runner, 1956, 1957, 1960). However, the earliest observation on such delayed blastocysts was ' 6 or 7 days' after a copulation plug was found (Smithberg \& Runner, 1960), i.e. 2 or 3 days later than the stage at which we examined our ovariectomized females. In delayed pregnancies of lactating mice, Enzmann et al. (1932) reported that the zona persisted 'till the end of the 5th day'; they concluded that loss of the zona is not delayed during lactation, but it is difficult to assess the weight of their evidence since the observations on which this conclusion is based were not published. Our own observations suggest that loss of the zona is in fact delayed in lactating mice (McLaren, unpublished) and rats (Orsini, unpublished).

Dickmann \& Noyes (1961) and Noyes, Dickmann, Doyle \& Gates (1963) found that 4th-day and 5th-day rat blastocysts transferred to opposite uterine horns of the same 4th-day pseudopregnant female shed their zonae at different times, corresponding to their different developmental stages. They concluded from this that 'shedding of the zona depends on the developmental stage of the ovum rather than on a specific uterine environment'. On the basis of our own results, we would modify this conclusion slightly, and suggest that the attainment by the ovum of a particular developmental stage is a necessary but not a sufficient condition for loss of the zona. When the appropriate developmental stage is reached, loss of the zona at the normal time is still dependent on an appropriate environment. The results of Dickmann \& Noyes (1961) and Noyes et al. (1963) suggest that this environment is provided by the 4th-day as well as the 5th-day rat uterus; on the other hand, our own work shows that it is not provided by the uteri of mice ovariectomized early in pregnancy, nor by the mouse oviduct. Whether the environmental factor acts on the zona, or affects the blastocyst primarily and the zona only secondarily, cannot yet be decided.

In the rat, the hormonal factor involved would appear to be oestrogen rather than progesterone. Mayer (1966) reported that loss of the rat zona is delayed, though not prevented, by hypophysectomy or by ovariectomy plus progesterone treatment; Meyer (1966) and Yasukawa \& Meyer (1966) confirmed that loss of the zona is delayed if ovariectomized females are maintained 
on progesterone alone, but found that the delay rapidly terminated when oestrogen was given.

Thus, loss of the zona appears to be progesterone-dependent in the hamster, oestrogen-dependent in the rat and perhaps also in the mouse. Such species differences may reflect fundamental differences in the endocrinology of pregnancy. The hamster has no post-partum oestrus or ovulation; ovulation occurs 4 days after parturition if the newborn young are removed, and 28 to 30 days after if the animal is allowed to lactate (Orsini, unpublished). No delay of implantation of the blastocyst has been reported; the blastocysts apparently implant at the normal time or not at all. Oestrogen does not seem to be required for implantation, since exogenous progesterone alone permits blastocysts to implant in females ovariectomized early in pregnancy (Orsini \& Meyer, 1959; Prasad, Orsini \& Meyer, 1960) or, after transfer, in ovariectomized and oophorectomized virgin females (Orsini \& Psychoyos, 1965). Both rats and mice, on the other hand, have a post-partum oestrus and ovulation; blastocysts from a post-partum mating will delay implantation if sufficient young are lactating. Bloch (1958) has shown that oestrogen, but not progesterone, will induce implantation in lactating mice. Duncan \& Lyster (1962) have shown that U-11555A can block oestrone-induced implantation in the rat, but has no effect on blastocysts in the hamster.

The mechanism of zona loss in rats and mice is still a subject of controversy. Mouse blastocysts cultivated in vitro under appropriate conditions have been observed to 'hatch' from the zona (Brinster, 1965; Cole \& Paul, 1965). Dickmann \& Noyes (1961) concluded that, in normal pregnancy also, the rat zona must be shed by the blastocyst rather than dissolved, since empty zonae were recovered by flushing the uterus, and several blastocysts were observed partway out of the zona. On the other hand it can be argued that if the zona is already weakened by lysis and blastocyst expansion, the act of flushing the uterus may rupture the zona and partly or completely release the blastocyst. Lysis of the zona has been observed by Dickson (1963) in the rat and by Orsini in the rat (Orsini, unpublished) and in the hamster (Orsini, 1963, 1964, 1965a). Mintz (1965) suggested that the mouse blastocyst may have two hatching mechanisms, of which one is the mechanical hatching characteristic of in-vitro cultivation. Alloiteau \& Psychoyos (1966), cited by Psychoyos (1965), have shown that ovariectomy of pregnant rats after the time of the 'oestrogen surge', followed by progesterone treatment, allows the zona to be lost at the normal time, apparently by lysis. If, on the other hand, the ovaries are removed earlier, or if the females are hypophysectomized on the 1st or 2nd day of pregnancy, loss of the zona is delayed by 3 to 4 days whether or not progesterone supplements are given, and occurs finally by rupture and hatching, leaving empty zonae which remain in the uterus for many days.

In no instance in the present series did we observe the thinning, blurring and 'fading out' of the zona, described by Orsini (1963, 1964, 1965a) and Dickson (1963) as characteristic of lysis in the hamster and rat, but since this is a relatively rapid process the chance of obtaining such a stage is anyway slight. In one instance (PI. I, Fig. 3) a blastocyst was seen in the normal series with a dilated zona, which in the hamster and rat has been observed to precede 
lysis. On the other hand, Cole \& Paul (1965) have described mouse blastocysts in culture undergoing a series of contractions and expansions before loss of the zona, and it may be that this dilated blastocyst represents an early stage in contraction, in which, as reported by Cole and Paul, recoil of the zona is usually slightly delayed relative to blastocyst shrinkage. Sudden contractions were seen in some of the blastocysts observed in the present series; the slower expansions were not observed, but may be represented by the variations in the size of the blastocysts and their zonae. Further, if lysis were the normal method of zona loss in the mouse, broken zonae would not have been recovered.

Our results support the idea that zona loss may occur in more than one way. In normal pregnancies (Table 1), empty zonae were recovered from only three females, and looked crumpled and opaque. Empty zonae were also recovered from two of the control horns in the tubal ligation series (Table 2). Ruptured zonae still containing blastocysts were not observed in control material. From the females ovariectomized early in pregnancy, by contrast, several blastocysts retained within cracked zonae were recovered (Table 3 ). From the ligated oviducts empty zonae were frequently recovered, fractured but otherwise intact and still transparent, and two blastocysts were found in the process of hatching (Table 2). The cracked and empty zonae which we observed in these circumstances (Pl. 3, Figs. 2, 6 and 7) appeared strikingly similar to those illustrated by Alloiteau \& Psychoyos (1966) in their Pl. 1, Figs. 9 to 12.

We suggest that the blastocyst-dependent factor in zona loss consists essentially of the hatching process observed in vitro, probably mediated by the pulsating movements reported by Cole \& Paul (1965). In a normal pregnancy, the zona pellucida is weakened by some factor of the oestrogenic uterus, acting either directly or through the agency of the blastocyst; in conjunction with the blastocyst's endogenous activity, this results in the shedding of the zona at the normal time. The action of the uterine factor would account for the distorted shape and non-elasticity of the zona pellucida shortly before it is lost; while evidence that even under uterine conditions, the blastocyst may emerge from the zona before lysis is complete comes from observations on serially sectioned uteri, where the remains of the shed zona may occasionally be observed lying near the naked blastocyst (McLaren, unpublished). The uterine factor on its own cannot wholly remove the zona, since in the mouse, unlike in the hamster, unfertilized ova never lose their zonae (Orsini, unpublished).

When the oestrogenic factor is absent or weak, e.g. in culture, after early ovariectomy or in the oviduct, the blastocyst may still succeed in escaping from the zona by its own unaided efforts, but it will take longer, and the cast-off zona will remain in a good state of preservation.

Variations in the relative importance of the blastocyst and uterine factors may explain a number of the differences between species which are so striking a feature in the loss of the zona.

\section{ACKNOWLEDGMENTS}

We would like to acknowledge support from the National Institutes of Health, grants HD-00267 and 8 (M.W.O.), and the Ford Foundation (A.McL.). 


\section{REFERENCES}

Allorteau, J. J. \& Psychoyos, A. (1966) Y a-t-il pour l'œuf de ratte deux façons de perdre sa zone pellucide? C.r. hebd. Séanc. Acad. Sci., Paris, 262, 1561.

Bı.och, S. (1958) Experimentelle Untersuchungen über die hormonalen Grundlagen der Implantation des Saügerheimes. Experientia, 14, 447.

BRINSTER, R. L. (1965) Studies of the development of mouse embryos in vitro: energy metabolism. Ciba Foundation Symposium, Preimplantation Stages of Pregnancy, p. 60. Churchill, London.

Burdick, H. O., Whitney, R. \& Pincus, G. (1936-37) The fate of mouse ova tube-locked by injections of oestrogenic substances. Anat. Rec.. Suppl., 67, 513.

Cochrane, R. L., Prasad, M. R. N. \& Meyer, R. K. (1962) Delayed nidation in the rat induced by autografts of the hypophysis with a case report of 'asynchronous implantation'. Endocrinology, 70, 228.

Cole, R. J. \& Paul, J. (1965) Properties of cultured preimplantation mouse and rabbit embryos, and cell strains derived from them. Ciba Foundation Symposium, Preimplantation Stages of Pregnancy, p. 82. Churchill, London.

Dickmann, Z. \& Noyes, R. W. (1961) The zona pellucida at the time of implantation. Fert. Steril. 12, 310.

Drckson, A. D. (1963) Disappearance of the zona pellucida from the rat blastocyst. F. Anat. 97, 620.

Dickson, A. D. (1966) The form of the mouse blastocyst. F. Anat. 100, 335.

Duncan, G. W. \& Lyster, S. C. (1962) Effect of U-11555A on blastocyst development. (Abstract). Fedn Proc. Fedn Am. Socs exp. Biol. 21, 437.

Enzmann, E. V., Saphir, N. R. \& Pincus, G. (1932) Delayed pregnancy in mice. Anat. Rec. 54, 325.

Finn, G. A. \& McLaren, A. (1967) A study of the early stages of implantation in mice. F. Reprod. Fert. 13, 259.

MAYER, G. (1966) In discussion; Ciba Foundation Study Group No. 23, Egg Implantation, p. 16. Churchill, London.

Meyer, R. K. (1966) In discussion; Ciba Foundation Study Group No. 23, Egg Implantation, p. 18. Churchill, London.

Mintz, B. (1965) In discussion; Ciba Foundation Symposium, Preimplantation stages of pregnancy, p. 167. Churchill, London.

Noyes, R. W., Dickmann, Z., Doyle, L. L. \& Gates, A. H. (1963) Ovum transfers, synchronous and asynchronous, in the study of implantation. In: Delayed Implantation. Ed. A. C. Enders. University of Chicago Press.

OrsinI, M. W. (1962) Technique of preparation, study and photography of benzyl-benzoate cleared material for embryological studies. $\mathcal{F}$. Reprod. Fert. 3, 283.

OrsinI, M. W. (1963) Morphological evidence on the intrauterine career of the ovum. In: Delayed Implantation. Ed. A. C. Enders. University of Chicago Press.

OrsinI, M. W. (1964) Implantation: a comparison of conditions in the pregnant and pseudopregnant hamster. 5th int. Congr. Anim. Reprod. Artif. Insem., Trento, 7, 309.

Orsini, M. W. (1965a) In discussion: Ciba Foundation Symposium, Preimplantation stages of pregnancy, p. 162. Churchill, London.

Orsini, M. W. (1965b) Factors affecting loss of the zona pellucida in the hamster. (Abstract). F. Anat. $99,922$.

ORSINI, M. W. \& MEYER, R. K. (1959) Implantation of the castrate hamster in the absence of exogenous estrogen. Anat. Rec. 134, 619.

Orsini, M. W. \& Psyghoyos, A. (1965) Implantation of blastocysts transferred into progesteronetreated virgin hamsters previously ovariectomized. (Abstract). F. Reprod. Fert. 10, 300.

Prasad, M. R. N., Orsini, M. W. \& MEYER, R. K. (1960) Nidation in progesterone-treated, estrogendeficient hamsters, Mesocricetus auratus (Waterhouse). Proc. Soc. exp. Biol. Med. 104, 48.

Psychoyos, A. (1960) La réaction déciduale est précedée de modifications précoces de la perméabilité capillaire de l'utérus. C.r. hebd. Séanc. Soc. Biol. 154, 1384.

Psychoyos, A. (1961) Perméabilité capillaire et décidualization utérine. C.r. hebd. Séanc. Acad. Sci., Paris, $252,1515$.

Psychoyos, A. (1965) In discussion: Ciba Foundation Study Group No. 23, Egg Implantation, p. 98. Churchill, London.

SmithBerG, M. \& RunNER, M. N. (1956) The induction and maintenance of pregnancy in prepuberal mice. F. $\exp$. Zool. 133, 441 .

Smithberg, M. \& Runner, M. N. (1957) Pregnancy induced in genetically sterile mice. F. Hered. 48, 97.

SmithreRG, M. \& RUNNER, M. N. (1960) Retention of blastocysts in nonprogestational uteri of mice. J. exp. Zool. 143, 21 . 
SNELL, G. D. (1956) The early embryology of the mouse. In: Biology of the Laboratory Mouse. (1st edn, 1941). Blakiston, Philadelphia.

TARKowski, A. K. (1962) Interspecific transfers of eggs between rat and mouse. F. Embryol. exp. Morph. $10,476$.

Wilson, I. B. (1963) A new factor associated with the implantation of the mouse egg. F. Reprod. Fert. $5,281$.

YAsukAwA, J. J. \& MEYER, R. K. (1966) Effect of progesterone and oestrone on the pre-implantation and implantation stages of embryo development in the rat. F. Reprod. Fert. 11, 245.

\section{EXPLANATION OF PLATES}

Plate 1

Figs. 1 to 5 . Ova flushed from the uterus during normal pregnancy, between 3 days $21 \mathrm{hr}$ and 4 days $2 \mathrm{hr}$ after ovulation (see Table 1). In these and other photographs of flushed ova, the optical focus is on the zona pellucida.

FIG. 1. Five of seven ova recovered from the female killed at 22.50 hours on the 4 th day of gestation. All are within the zona, but size and morphology are variable. $\times 180$.

Fig. 2. Blastocyst recovered from the female killed at 02.45 hours on the 5 th day of gestation. Note the shrunken zona, moulded to the contour of the blastocyst. $\times 288$.

Frg. 3. The two blastocysts in zonae recovered from the female killed at 23.25 hours on the 4th day of gestation. Note that the zona of one is expanded (indicated by arrow). $\times 90$.

Fig. 4. One zona-free blastocyst and two in zonae, recovered from the female killed at 23.50 hours on the 4 th day of gestation. $\times 288$.

FIG. 5. Two elongated zona-free blastocysts recovered from the female killed at $25 \mathrm{~min}$ past midnight, on the 5th day of gestation. $\times 180$. These blastocysts are typical of the elongated forms recovered after attachment has been initiated.

Fig. 6. Transverse section $(6 \mu)$ of an implantation site from the unflushed horn of the female killed at 23.10 hours on the 4th day of gestation. The blastocyst is in contact with the uterine epithelium. Note the dark W-body entering the epithelium on the left of the blastocyst. Here and in Fig. 8, the mesometrial side of the uterine horn is towards the top of the page. $\times 450$.

Fig. 7. Cleared uterine horn from the control non-ligated side of the female from the tubal ligation series killed at 11.30 hours on the 7th day of gestation. Two of the four implantation sites are shown. The antimesometrial portion of the conceptual swelling (to the right) appears clearer and less opaque than the mesometrial. $\times 7$.

Fig. 8. Transverse section of one of the conceptual swellings shown in Fig. 3. Inversion has occurred, and giant cells are present beneath the anti-mesometrial portion of the ectoplacental cone. $\times 180$.

\section{Plate 2}

Tubal ligation series (see Table 2). Ova flushed from the ligated oviducts and control uterine horns on the 5th day of gestation, between 4 days $7 \mathrm{hr}$ and 4 days $17 \mathrm{hr}$ after ovulation.

FIG. 1. The six blastocysts, all in zonae, recovered from the ligated oviduct of the female killed at 08.55 hours. Note the size variation among these blastocysts: the more expanded the blastocyst, the narrower is the space between blastocyst and zona. $\times 288$.

FIG. 2. One of the two zona-free blastocysts recovered from a portion of the control uterine horn of the female killed at 17.45 hours. $\times 360$.

Fig. 3. Blastocyst in zona, recovered from the ligated oviduct of the female killed at 17.10 hours. This blastocyst was beginning to hatch: note the bleb protruding through the zona pellucida at the point indicated by the arrow. $\times 180$.

Fig. 4. Ova recovered from the ligated oviduct of the female killed at 16.05 hours. Six blastocysts, in various stages of contraction, retain the zona; one contracted blastocyst is zona-free. One empty zona, out of focus, is indicated by an arrow. The uncleaved ovum (o) looks like a typical ovarian oocyte, and was probably nicked from the ovary in the process of flushing. $\times 225$.

FIG. 5. The one blastocyst recovered from the ligated oviduct of the female killed at 13.45 hours. This blastocyst began to hatch while being observed under the microscope; the abembryonic portion was the first to emerge. $\times 288$. 


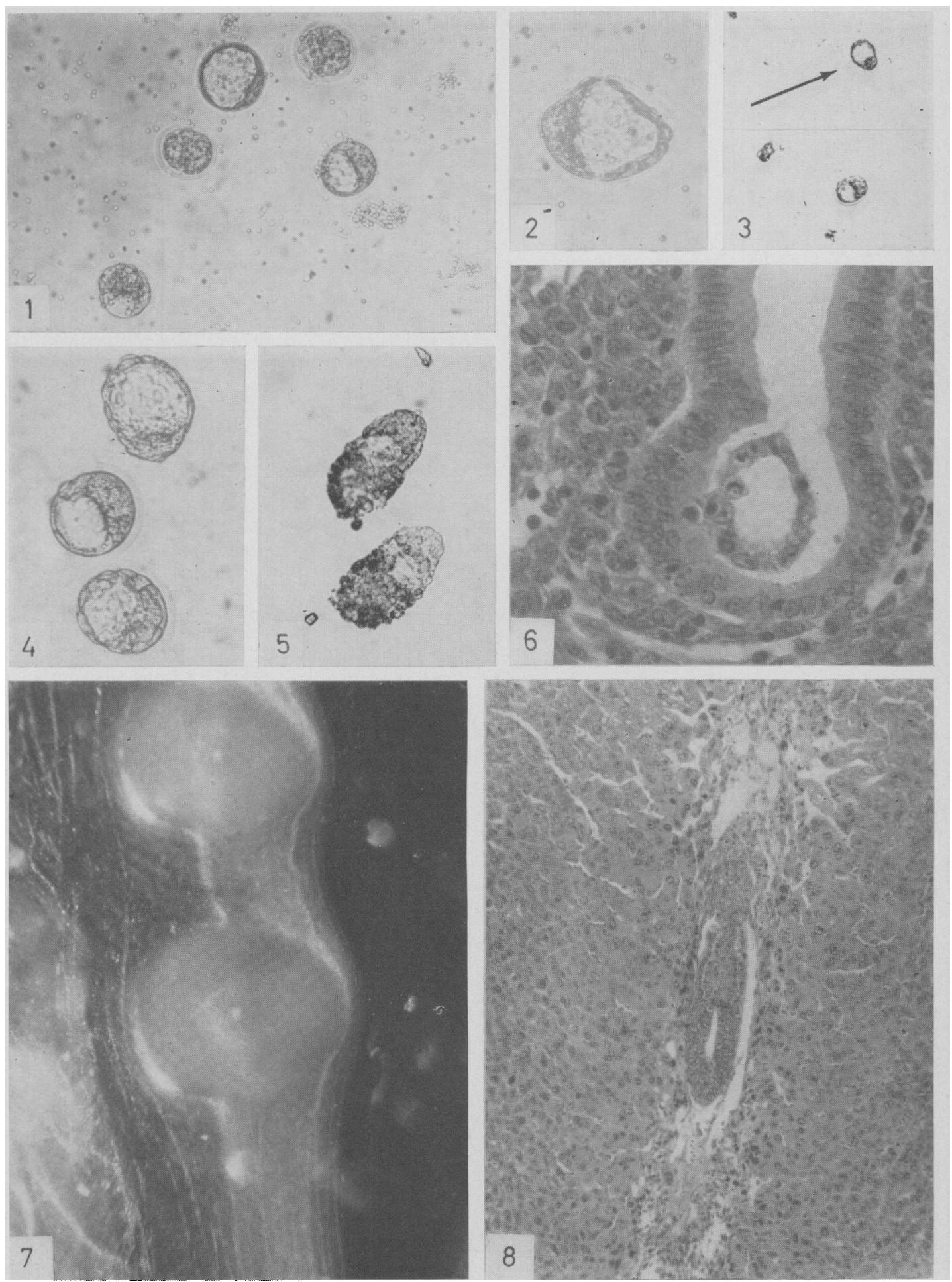

facing $p .498$ 
PIATE 2
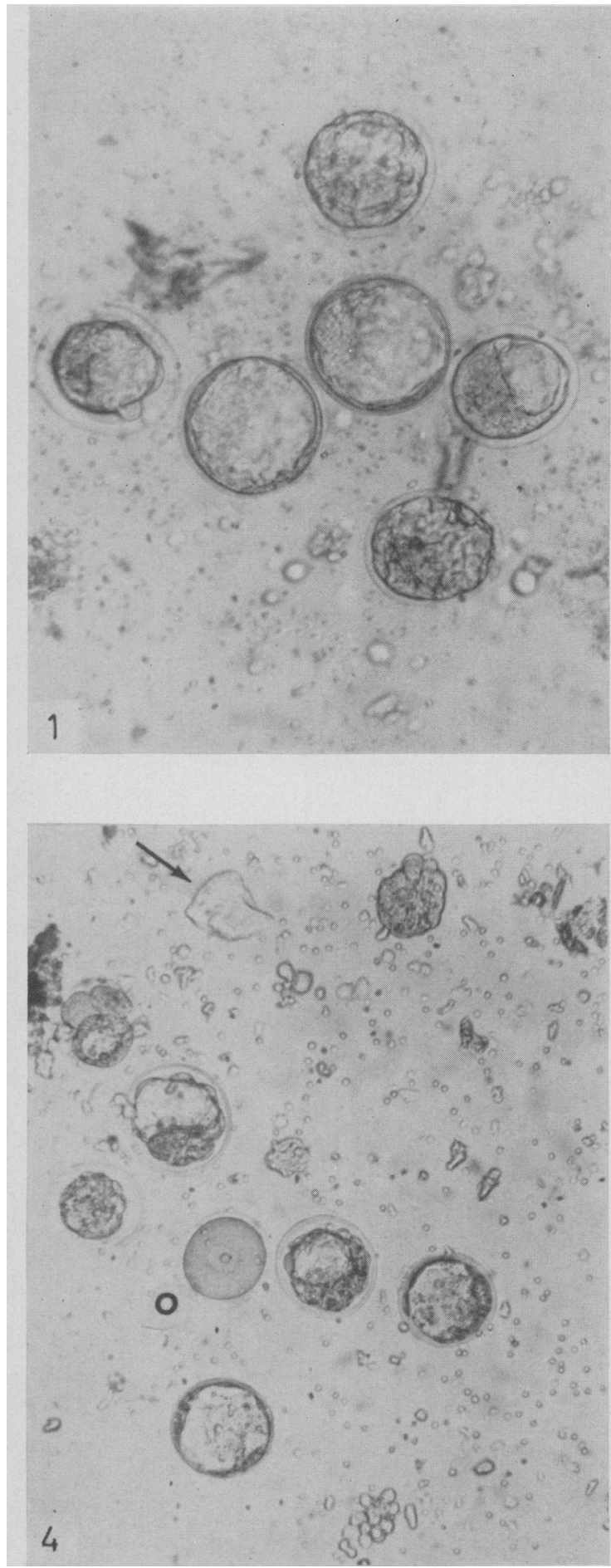
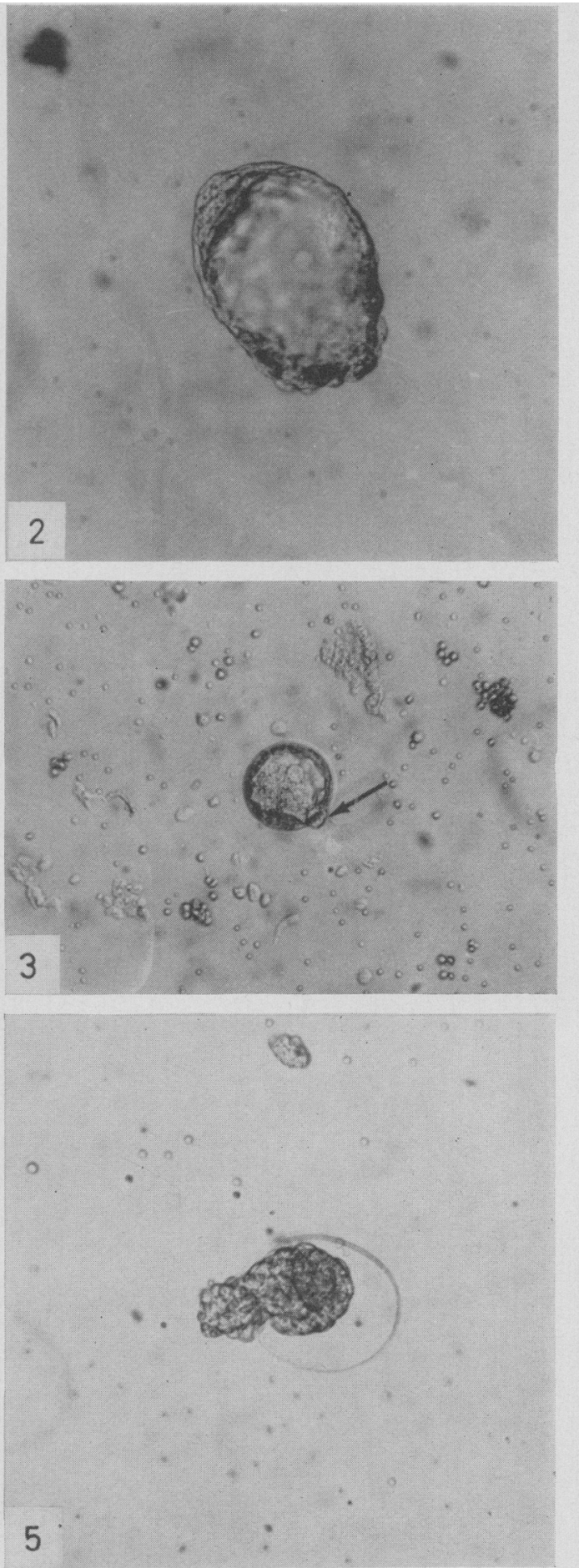
PLATE 3
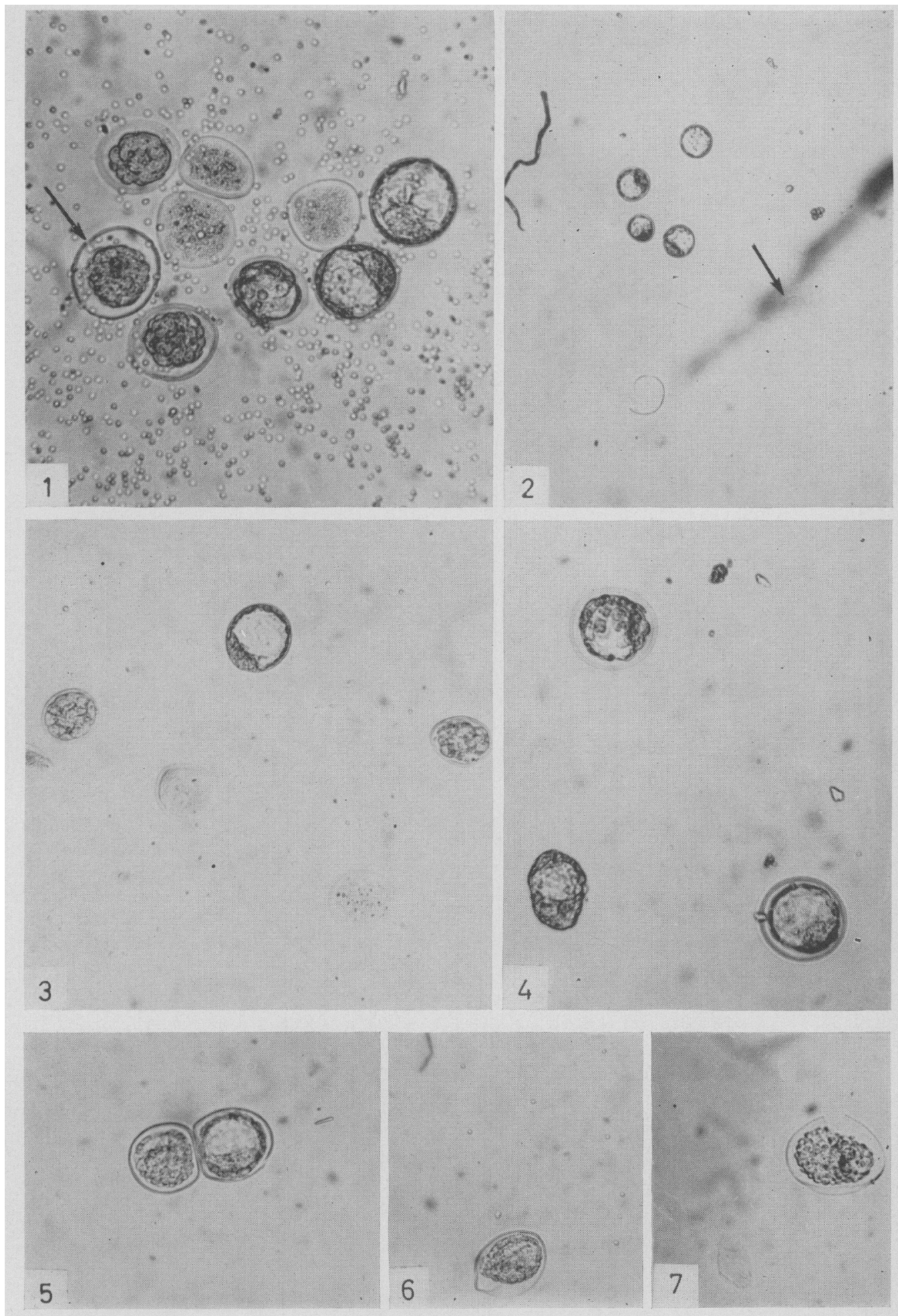
Plate 3

Ova flushed from the uterine horns of ovariectomized females (see Table 3 ) on the 5 th day of gestation, between 4 days $7 \mathrm{hr}$ and 4 days $12 \mathrm{hr}$ after ovulation.

Fig. 1. Ova recovered from the left uterine horn of the female killed at 13.00 hours. Four of the blastocysts were in intact zonae (one could either be a late morula or a fully contracted blastocyst), and two were in zonae showing cracks (one of these is indicated by an arrow), similar to those shown in Figs. 6 and 7. The three 'dispersed' ova could either be unfertilized or very degenerate fertilized ova. $\times 225$.

FIG. 2. The four blastocysts in zonae and two empty zonae recovered from the female killed at 14.30 hours. One of the empty zonae is cracked wide open like the hull of a horse chestnut, but has retained its general rounded contour; the other, indicated by an arrow, is slightly out of the optical plane. $\times 90$.

Fig. 3. Three blastocysts and two 'dispersed' ova, all in zonae, recovered from the female killed at 11.05 hours. Only one of the blastocysts looked completely normal. $\times 180$.

Fig. 4. Three blastocysts, two in zonae and one free, recovered from the female killed at 08.45 hours. All looked normal. $\times 225$.

Figs. 5 to 7 . Four blastocysts recovered from the female killed at 12.25 hours. $\times 180$. Fig. 5. Two blastocysts in intact zonae, stuck together. Figs. 6 and 7. Two blastocysts in ruptured zonae. 